\title{
MEDIJSKA PREZENTACIJA ZAGREBAČKOG ADVENTA: BIZNIS, EKSPLOATACIJA, IDENTITET
}

Prethodno priopćenje Primljeno: 1. 7. 2018. Prihvaćeno: 27. 9. 2018. DOI: $10.15176 /$ vol55no205 UDK 316.774:398.332.41(497.521.2) $659.443 / .446$

\author{
NINA OŽEGOVIĆ \\ Institut za kulturu i etiku, Odsjek za komunikologiju, \\ Hrvatski studiji Sveučilišta u Zagrebu
}

\begin{abstract}
U ovom se radu metodom analize sadržaja istražuje priroda medijskih napisa u prezentaciji manifestacije Advent u Zagrebu. Analiziraju se prilozi objavljeni u domaćim tiskanim i elektroničkim medijima s naglaskom na dnevnike Jutarnji list i Večernji list te tjedne internetske portale Novosti i Telegram. Posebno se istražuje pitanje pridonosi li medijska prezentacija isključivo adventizaciji i festivalizaciji zagrebačkih prostora odnosno razvoju poduzetničkih kapaciteta, ili doprinosi i stvaranju novog urbanog i kulturnog identiteta Zagreba kao "adventske metropole". Također, nastoji se ispitati vidi li se iz medijskih napisa kakav identitet Zagreba kreira gradska uprava posredstvom manifestacije Advent u Zagrebu. Osobit se fokus u radu usmjerava prema nekritičnom i euforičnom pisanju o novom "adventskom" identitetu Zagreba.
\end{abstract}

Ključne riječi: advent, medijska prezentacija, identitet Zagreba, festivalizacija, eventizacija

\section{UVOD}

Rad polazi od hipoteze da je manifestacija Advent u Zagrebu umnogome oblikovana političkim, gospodarskim i kulturnim kontekstom postsocijalističkog i posttranzicijskog društva, koji od devedesetih u velikoj mjeri utječe i na promjenu položaja i uloge medija u Hrvatskoj. ${ }^{1}$ Društvo se od 2000. godine sve više spektakularizira, ${ }^{2}$ od političke arene

${ }^{1}$ Hrvatski medijski prostor karakteriziraju komercijalizacija, tržišna diktatura, rast korporativnih medijskih industrija i njihov utjecaj na objektivnost izvještavanja, depolitizacija, deprofesionalizacija i senzacionalizam.

2 Spektakularizacija svakodnevice postoji u različitim formama od antičke Grčke i starog Rima, no od kraja devedesetih godina prošlog stoljeća taj trend spektakularizacije društvenog života određuje i "prividna dezideologizacija, tj. tendencije odbacivanja i oslobađanja od svakog vida 'teških' pristupa temama političkog, ekonomskog, kulturnog i općedruštvenog tipa, ali je kao takav zapravo klasičan primjer ideološke matrice" 
do svakodnevnice, a trend estradizacije ${ }^{3}$ vidljiv je i na stranicama hrvatskog tiska. S tim promjenama dolazi i do reafirmacije uloge religije i Crkve na razini sustava, države i politike, a bilježi se i porast konfesionalnog izjašnjavanja i sudjelovanja u religijskoj praksi. ${ }^{4}$ Slavljenje Božića zauzima sve više prostora u medijskoj produkciji. Ubrzo počinje i slavljenje adventa. Božić, kao i advent, postaje sastavni dio medijske slike Hrvatske.

Premda su mediji od osnutka manifestacije Advent u Zagrebu 2010. godine vrlo opširno i učestalo izvještavali o toj manifestaciji, sadržaj, poruke i vrijednosni signali medijskih napisa o tom događaju dosad nisu znanstveno analizirani i vrednovani. Zbog toga ovaj rad nastoji metodom analize sadržaja ${ }^{5}$ istražiti modele medijske prezentacije Adventa u Zagrebu te na temelju rezultata utvrditi utjecaj i doprinos medija u kreiranju novog identiteta "Zagreba kao najbolje adventske lokacije" (Golemac 2018). Drugim riječima, rad se bavi pitanjem utječu li mediji na brendiranje Zagreba kao "adventske metropole s vrhunskom gurmanskom street ponudom" ${ }^{6}$ ili novu sliku grada temelje, primjerice, i na kulturnim programima manifestacije Advent $u$ Zagrebu, koji bi mogli pozicionirati Zagreb kao grad značajnog kulturnog kapitala. Također, analizom službenih i promotivnih materijala o manifestaciji Advent u Zagrebu, koji su objavljeni na internetskim stranicama manifestacije Advent u Zagrebu, ${ }^{7}$ Grada Zagreba, ${ }^{8}$ Turističke zajednice grada Zagreba $^{9}$ i političke stranke Bandić Milan 365-Stranka rada i solidarnosti, ${ }^{10}$ nastoji se ispitati odnos

(Hromadžić 2011: 619). Taj suvremeni trend podržan je djelovanjem masovnih medija, koji posreduju informacije kroz matrice infotainmenta (spoj informacije i zabave) i infomerciala (spoj informacije i komercijale), što pak pridonosi "depolitizaciji društva u cjelini” (isto).

${ }^{3}$ Estradizacija medijskog prostora određena je proizvodnjom celebrity kulture i tzv. star-sistema, što "depolitizira društvo i svodi ga na obično naklapanje", a "pozornost se preusmjerava s bitnih, društvenih i političkih događaja na nebitne sadržaje [...] koji se zatim dramatiziraju i predstavljaju kao stvarni problemi društva" (Bourdieu 2000: 72).

${ }^{4}$ Rezultati istraživanja "Religijske promjene i vrijednosti u hrvatskom društvu" koje je 1999. godine proveo Institut za društvena istraživanja (voditelj projekta Nikola Skledar) pokazuju da je u devedesetim godinama 20. stoljeća došlo do porasta religioznosti, te da dominiraju oni elementi religioznosti koji nose pečat tradicionalno običajnog: vjenčanje u crkvi, krštenje djece, vjerski odgoj te slavljenje većih vjerskih blagdana. Također je utvrđeno da je promjenom političkog sustava u Hrvatskoj religija ponovo stekla status priznate društvene vrijednosti što se odrazilo i na položaj religije i Crkve u društvu, te na povećano iskazivanje i manifestiranje religioznosti na individualnoj razini (Labus 2000).

${ }^{5}$ Najpoznatije definicije metode analize sadržaja donose Harold D. Lasswell i Bernard Berelson. Laswell (1948: 37) je definira "kao tehniku istraživanja koja služi za objektivno, sustavno i kvantitativno opisivanje izrečena sadržaja", a Berelson (1959: 1-6) "kao istraživačku tehniku za objektivno opisivanje, sistematiku i kvantifikaciju manifestnih sadržaja u komunikacijama”. Često se upotrebljava Laswellova formula koja služi za analizu cjelokupne komunikacije masovnih medija, a glasi: "Tko kaže što, kome, zašto, koliko opsežno i s kakvim učinkom?" (1948: 38-40). Stoga je u radu korištena metoda analize sadržaja kako bi se utvrdile specifičnosti i međusobne razlike tekstualnog i vizualnog materijala o manifestaciji Advent u Zagrebu u odabranim hrvatskim medijima.

${ }^{6}$ https://www.jutarnji.hr/life/advent-zagreb/video-posjetitelji-odabrali-najbolju-adventsku-lokaciju-zagreba-odusevili-tisuce-zbog-urbanog-koncepta-lijepih-standova-i-dobre-hrane/6883596/ (pristup 8. 4. 2018.).

${ }^{7}$ www.adventzagreb.hr.

${ }^{8}$ https://www.zagreb.hr/secer-dolazi-na-krajugodine-poceo-advent-u-zagrebu/118939.

${ }^{9}$ www.tzgz.hr/aktualnosti/advent-u-zagrebu (pristup 10. 5.2018.).

${ }^{10}$ www.365ris.hr/portfolio/advent-u-zagrebu-2/ (pristup 10. 5. 2018.). 
aktualne politike, tj. gradske uprave, i medijske slike Adventa u Zagrebu, te utvrditi u kojoj se mjeri službene poruke prenose u medijskim prilozima.

Istraživanje se usredotočilo na medijske napise koji su objavljivani u razdoblju od 1. prosinca 2017. do 8. siječnja 2018. godine, dakle za vrijeme trajanja sajma. Obuhvaćeni su prilozi u internetskim izdanjima komercijalnih, tržišno orijentiranih, mainstream dnevnika - Jutarnjem listu i Večernjem listu te u elektroničkom tjedniku Telegram i internetskom izdanju tjednika Novosti, koje karakteriziraju viši stupanj analitičnosti i kritičniji diskurs. Ti su mediji izabrani da bi se ispitalo kako različite izdavačke politike i uređivačke orijentacije te dnevni odnosno tjedni ritam izlaženja utječu na medijsku prezentaciju istog događaja - manifestacije Advent u Zagrebu.11 Također, presudna je bila tiraža odnosno čitanost i posjećenost internetskih stranica tih medija u 2017. godini, a vezano uz pretpostavku o utjecaju na javno mnijenje u Hrvatskoj.12

Istraživanju medijske slike Adventa u Zagrebu pristupilo se interdisciplinarno, a korištene su teze i razmišljanja predstavnika Frankfurtske škole Maxa Horkheimera i Theodora Adorna, teoretičara medija Marshalla McLuhana, aktivista Guya Deborda, urbanog sociologa Manuela Castellsa, filozofa i političkog aktivista Noama Chomskog, francuskih mislilaca Pierra Bourdiea i Jeana Baudrillarda, politologa Thomasa Meyera i etnologinja Dunje Rihtman-Auguštin, Petre Kelemen i Nevene Škrbić Alempijević te još nekolicine autora.

\section{MEDIJSKA PREZENTACIJA ADVENTA U ZAGREBU}

\section{ADVENT U SUVREMENOJ HRVATSKOJ}

Etnologinja Dunja Rihtman-Auguštin u knjizi Ulice moga grada (2000) piše o oživljavanju zaboravljenih i zabranjenih tradicija i simbola, te o uspostavljanju novih nacionalnih političkih

${ }^{11}$ Tjednici Nacional i Globus nisu odabrani za analizu zato što nemaju slobodan pristup internetskim stranicama, a i po profilu su slični Jutarnjem listu i Večernjem listu.

12 Posjećenost, tzv. klikanost internetskih portala mjere različite platforme kao što su Gemius, Google Analytics i DotMetrics, a rezultati su namijenjeni prvenstveno izdavačima, oglašivačima i marketinškim agencijama. Podaci o "klikanosti” pojedinih portala javnosti su dostupni jedino na portalu Gemius dok ostali servisi javnosti nude samo zbirne podatke o korištenju interneta u Hrvatskoj. Mediji povremeno na svojim stranicama objavljuju podatke o posjećenosti svojih portala, no pitanje je koliko su takve informacije vjerodostojne. Tako Večernji list 1. ožujka 2017. objavljuje članak u kojem tvrdi da su dnevnici grupacije Styria 24sata i Večernji list bili najposjećeniji dnevnici u Hrvatskoj (prvo i drugo mjesto). (https://www.vecernji.hr/techsci/ povijesna-dominacija-styrije-na-domacem-trzistu-1153087, pristup 22. 9. 2018.).

Međutim, Hanza media d.o.o. (izdavač Jutarnjeg lista) 2. ožujka 2017. objavljuje prilog u kojem tvrdi da je prema podacima DotMetricsa Jutarnji list najposjećeniji portal u Hrvatskoj. Hanza media d.o.o. u ožujku 2017. napušta Gemius zbog sumnje u objektivnost njihovog mjerenja. Naime, prema rezultatima portala Gemius Jutarnji list je u veljači 2017. bio tek na četvrtom mjestu što se nije podudaralo s podacima DotMetricsa. (https://www.jutarnji.hr/vijesti/hrvatska/stigli-podaci-za-veljacu-jutarnjihr-uvjerljivo-najcitaniji-u-hrvatskoj-vise-od-13-milijuna-posjetitelja-i-vise-od-34-milijuna-posjeta/5711035/, pristup 22. 9. 2018.).

Rasprava se dalje razvijala na portalu fairpress.eu (http://www.fairpress.eu/hr/blog/2017/04/05/ hanza-media-napustila-gemius-ne-zelimo-vjerovati-da-je-u-pitanju-padanje-pozicije-jutarnji-hr-na-ranking-listi-tijekom-nekoliko-prethodnih-mjeseci/, pristup 22. 9. 2018.). 
rituala. Donosi i povijesni okvir adventa, te ističe da je u nas "adventski vijenac općenito novija tradicija" (Rihtman-Auguštin 2000: 157). Citirajući etnologinju Ingeborg Weber-Kellermann autorica u nastavku kaže da se u Njemačkoj advent javlja u građanskoj obitelji na prijelazu stoljeća, kasnije i u uredima, "podržavan vjerskom pedagogijom" i u okviru "buržuizacije božićnih običaja, vjerojatno ne bez utjecaja cvjećarske proizvodnje" (isto). Potom pojašnjava da su "protestantske tradicije poput Malog Božića i adventskog vijenca, sastavnice građanske kulture, prodirale iz protestantskog sjevera na katolički jug njemačkog govornog i kulturnog prostora. A odatle je tek korak do hrvatskih građanskih sredina" (isto: 156). Tako su dospjele i u naše krajeve.

U istoj knjizi objašnjava kako se "još jedan izum građanskog Božića doselio k nama zajedno s 'demokratskim promjenama' - adventski vijenac. Njegova pedagoška funkcija dopire u naše domove zadnjih nekoliko sezona, kada nam četiri svijeće svjetlucaju s malog ekrana dok političari razgovaraju i pregovaraju" (isto: 157). Prema njezinom mišljenju ljudi su "nakon dugotrajnog razdoblja potiskivanja Božića svetkovanje tog blagdana, i cijelog ciklusa blagdana i običaja što ga prate, doživljavali kao ostvarenje svoga vjerskoga, ali i ljudskoga prava" (isto: 143).

Autorica također smatra da je Božić postao simbolom nacionalnoga identiteta. "U novim okolnostima katolička crkva bijaše vrlo djelotvorna: ne samo s propovjedaonice nego i u novinama, na radiju i televiziji duhovnici nakon pola stoljeća šutnje javno i autoritativno tumače narodu biblijsku legendu o Božjem utjelovljenju i pronose božićne poruke mira" (isto). Na političkoj sceni, objašnjava autorica, postkomunistička vlast je "restaurirala i oblikovala javne božićne običaje na svoju sliku i priliku. U okviru općih tendencija preutemeljenja hrvatske kulture stranka na vlasti trudila se zadržati glavnu riječ u određivanju značenja hrvatskog Božića. Državni mediji sugestivno su 'predlagali', među ostalim, kako slaviti pojedine faze blagdanskog ciklusa, s kojim se simbolima i drugim parafrenalijama služiti i kako ih imenovati" (isto: 144).

Slijedom autoričina gledišta da su "postupci preimenovanja (ulica) samo dio napora za preutemeljenje nacije, njezine ideologije, njezine kulture, jednom riječju naših svjetonazora" (isto: 60), može se reći i da su novoutemeljeni sajmovi i festivali, koji se pozivaju na običaje, također sredstvo preutemeljenja nacije. U Hrvatskoj je "vjerojatno kao malo gdje drugdje u komunističkom i postkomunističkom svijetu, veliki blagdan narodne kulture - Božić bio i ostao barometrom naših mentaliteta i politika" (isto: 162). Stoga je postsocijalistički Božić moguće shvatiti kao "izraz oduška" (isto), a mogla bi se postaviti i "hipoteza o postepenoj pretvorbi narodnih vjerskih praznika u nacionalne, hrvatske praznike" (Rihtman-Auguštin 1992: 39).

\section{MEDIJSKA SLIKA ADVENTA U KONTEKSTU DIKTATURE PROFITA}

Analiza elektroničkih dnevnika i tjednika (Jutarnji list, Večernji list, Novosti i Telegram) pokazala je da mediji ne promatraju manifestaciju Advent u Zagrebu kao slojevit kulturni, 
gospodarski, gastronomski i turistički fenomen, dakle kao cjelinu različitih značenja koja može biti značajna u proizvodnji novog identiteta grada.

Premda se na službenim internetskim stranicama manifestacija reklamira kao "poseban umjetnički kulturni program s naglaskom na umjetnost i promociju umjetničkih djela, kulturnih aktivnosti i umjetnika",13 mediji u svojim prilozima u potpunosti zanemaruju predstavljanje i recenziranje kulture (u užem smislu) i kulturnih događanja na sajmu. U najboljem slučaju donose se popisi glazbenika koji nastupaju na manifestaciji. Također, ne prepoznaju manifestaciju kao prostor za moguću kulturnu kreaciju ili trajnu revitalizaciju grada, nego je u većini priloga promatraju kao komercijalni gastro-turistički proizvod koji je usmjeren prema zabavi, užitku i potrošnji. U medijskoj slici adventa naglasak je na prikazu sceničnog gradskog spektakla - "zanimljiva i inovativna scenografija, bajkovito mjesto, prekrasan tunel iz najljepših bajki" (Macukić 2017a), na raskošnoj gastro ponudi - "gastronomska ponuda nikad nije bila bogatija”, “dojmljiva prezentacija jela” (Babić i Šarić 2017a) i masovnom okupljanju Zagrepčana i turista - "rekordna brojka posjećenosti", "najviše stranih dolazaka bilo je iz Italije, Bosne i Hercegovine, Austrije, Slovenije, Njemačke, Koreje, Srbije, azijskih zemalja, SAD-a i Velike Britanije" (Golemac 2018), koji kroz strategiju zabave i gozbe ostvaruju identifikaciju s gradom i zajednicom. Zašto? Jer takav hedonistički medijski prikaz Adventa u Zagrebu pridonosi porastu novinskih tiraža i "klikanosti" na portalima što znači da je profitabilan i tržišno isplativ.

U dešifriranju medijske poruke važne informacije pruža i uvid u one sadržaje koji su neobjavljeni, prešućeni. Nije zabilježen niti jedan članak u kojem se definira je li Advent u Zagrebu sajam, festival, svetkovina ili manifestacija. Uglavnom se koristi odrednica sajam iako se na službenim stranicama organizatora najčešće spominje termin turističko-blagdanska manifestacija. Nije pronađen ni jedan napis o promjenama i adaptacijama adventa, a niti u jednom članku nije analizirana uloga adventa u današnjoj Hrvatskoj, kao ni uloga svetkovina i tradicijske kulture u suvremenom kontekstu. Također, tijekom analize za potrebe ovoga članka nije pronađen niti jedan prilog u kojem se istražuje ili barem spominje odnos između politike, tj. gradske vlasti i adventa, odnosno između Crkve i manifestacije Advent u Zagrebu, koji bi pridonio razumijevanju zagrebačkog adventa $u$ današnjem društvenom i kulturnom kontekstu.

Promjena položaja i uloge medija u postsocijalističkom i posttranzicijskom hrvatskom društvu određena je stvaranjem tržišta i uspostavljanjem diktature profita, koja je dovela do maksimalne komercijalizacije svih medijskih sadržaja. To je rezultiralo tabloidizacijom, estradizacijom i trivijalizacijom cjelokupnog medijskog prostora i redefiniranjem načina na koji se prezentira sadržaj, a posebno kada je riječ o prilozima o kulturi. Informacija je pretvorena u robu, a s druge je strane došlo i do manipulacije medijskim sadržajima. Još su Horkheimer i Adorno oštro kritizirali manipulativno-propagandni utjecaj masovnih me-

${ }^{13}$ www.adventzagreb.hr (pristup 10. 5. 2018.). 
dija, ali i njihovu komercijalizaciju, te utjecaj tržišta na medije koji je doveo do pasivizacije čitalaca (Horkheimer i Adorno 1989: 126-172).

Sociolog Manuel Castells u knjizi Uspon umreženog društva govori o usponu novog tipa društva - informacijskog kapitalizma, odnosno informacionalizma (Castells 2000: 53), koji vodi stvaranju “umreženog društva" i "kulture stvarne virtualnosti”. Prema njegovu mišljenju, prodor globalizacijskih trendova i opća komercijalizacija svih područja života zahvaća i informatičku superautocestu, te se sukladno tome može reći da se sablast profita nadvila i nad medije. I hrvatski medijski prostor doživljava transformaciju i već se u devedesetima uspostavlja tržišno, komercijalno novinarstvo. Medij, odnosno informacija / medijski sadržaj počinju se promatrati i vrednovati kao i svaki drugi proizvod - kao roba koja donosi dobit. Zbog te opće merkantilizacije svjetskog i hrvatskog medijskog prostora dolazi do zaokreta u sadržajnom konceptu medija koji pokušavaju "odvratiti pozornost s bitnog na nebitno, površno i zabavno" (Chomsky 2005: 199). Kulturna proizvodnja nije utrživi medijski sadržaj. Utrživ je spektakl, koji danas predstavlja, kako tvrdi filozof i zagovornik situacionističke teorije Guy Debord, "vladajući oblik života" (Debord 1999: 36-37). Istodobno, od 2000. godine, bilježe se značajne promjene u području medija. Jean Baudrillard definira svijet medijske kulture kao "svijet simulakruma" (Baudrillard 2001: 4), a u radu "Iznad istinitog i neistinitog" navodi da "medijska proizvodnja pseudodogađaja" rezultira "pseudokulturom u kojoj se događa falsificiranje autentičnog sadržaja" (Baudrillard 2005: 189). Pierre Bourdieu naglašava da "malo pomalo televizija koja nastoji biti sredstvom bilježenja postaje sredstvom stvaranja zbilje" (Bourdieu 2000: 37). Castells pak govori o "kulturi stvarne virtualnosti" (Castells 2000: 400), ${ }^{14}$ a McLuhan o izdrobljenoj, filtriranoj, nanovo interpretiranoj supstanci svijeta (McLuhan 2008).

Hajrudin Hromadžić u članku "Mediji i spektakularizacija društvenog svijeta” ističe kako je fenomen spektakularizacije društva bio prisutan i u ranijim razdobljima, ali "specifikum društva spektakla i celebrity kulture, kako ih poimamo u suvremenom smislu tih termina, jest nezanemariva uloga i podrška masovnih medija u promoviranju vrijednosnih modela koji se svrstaju pod te dvije, njima srodne odrednice" (Hromadžić 2011: 624). U istom članku govori i o autentičnim ljudskim potrebama koje su u tržišnim ekonomijama zamijenjene s tzv. pseudo-potrebama te dominiraju nad čitavim poljem društvenog života. Tvrdi da je konstruiranje tih pseudo-potreba u nadležnosti masovnih medija i oglašivačkih agencija, te zaključuje da time "svakodnevni život dospijeva pod invaziju kulture spektakla kasnog kapitalizma u kojem je svijet nemoguće obuhvatiti u njegovoj neposrednosti, nego tek preko serija apstrakcija i medijatiziranih predstava" (isto).

Bourdieu zaključuje da je "definitivno nestalo pedagoško-paternalističko novinarstvo koje je imalo kulturne pretenzije i oblikovalo širi ukus publike, a zamijenilo ga je populistič-

${ }^{14}$ Manuel Castells u djelu Uspon umreženog društva objašnjava novi komunikacijski sustav koji, suprotno prijašnjim povijesnim iskustvima, proizvodi stvarnu virtualnost. Prema Castellsu riječ je "o sustavu u kojem je sama stvarnost (tj. ljudsko, materijalno/simboličko postojanje) u potpunosti obuhvaćena, posve uronjena u virtualnu postavu slika, u izmišljeni svijet, u kojemu pojave ne postoje samo na ekranu pomoću kojeg se iskustvo komunicira, već same postaju iskustvo" (Castells 2000: 400). 
ko, koje podilazi ukusu publike, promovira mediokritete i svodi život na anegdotu, senzaciju i sliku" (Bourdieu 2005: 270). U takvom novinarstvu, ističe on, dominira "načelo zaborava koje daje prednost trivijalnijim temama te mediji idu u smjeru zabave, uspavljivanja, odnosno, anestetiziranja čitatelja" (isto: 275), dok je kritički i analitički diskurs iskliznuo sa stranica tiska. Taj trend prema revijalizaciji medija i trivijalizaciji sadržaja te konstrukciji nove zbilje putem medija vidljiv je i u hrvatskim medijima.

Promoviraju li mediji model adventizacije ${ }^{15}$ različitih zagrebačkih prostora u kojem su naglašene strategije festivalizacije, ${ }^{16}$ eventizacije i razvoja poduzetničkih kapaciteta ${ }^{17} \mathrm{u}$ afirmiranju novog identiteta Zagreba kao adventske metropole, ili se pak usredotočuju na potragu za dodanom vrijednošću, kao što je obnova javnih prostora grada i brendiranje autentične zagrebačke baštine i kulture?

\section{ODNOS ORGANIZATORA MANIFESTACIJE I MEDIJSKE SLIKE ADVENTA U ZAGREBU}

Usporedbom službenih informacija o manifestaciji Advent u Zagrebu, koje su objavljene na internetskim stranicama inicijatora i organizatora sajma (Grada Zagreba, Turističke zajednice grada Zagreba i političke stranke Bandić Milan 365-Stranka rada i solidarnosti), te same manifestacije, ovaj rad nastoji ispitati odnos aktualne politike, tj. gradske uprave, i medijske slike Adventa u Zagrebu, ali i ustanoviti u kojoj se mjeri medijski diskurs razlikuje od onog službenog.

Analizom je, ponajprije, utvrđeno da se na internetskim stranicama Adventa u Zagrebu taj sajam definira kao "najvažnija turističko-blagdanska manifestacija Zagreba",18 a posebno se naglašava trostruka titula Best Christmas Markets, koju je Zagreb osvojio tri godine zaredom glasovanjem čitatelja na natječaju internetskog portala European Best Destinations. ${ }^{19}$ Dominira sladunjavi promidžbeni diskurs kojim se, u skladu sa sloganom

${ }^{15}$ Pojam adventizacije pojavljuje se u hrvatskom medijskom prostoru od 2016. godine i njime se opisuje širenje adventskih, blagdanskih sadržaja u gradskim prostorima i atmosferi u vrijeme adventa u Zagrebu i ostalim hrvatskim gradovima. Pojavljuju se i druge nove kovanice, kao što su adventiranje i adventurizam (vidi npr. Dumančić 2016 i tris.com.hr/2017/12/opca-adventizacija-plenkovic-zapalio-svijecu-predsjednica-rh-bi-istinski-duh-bozica-a-bandic-vise-osmijeha-i-zagrljaja/, pristup 10. 9. 2018.).

16 Termin festivalizacija u ovom se kontekstu koristi kao "proces stvaranja festivala" (Kelemen i Škrbić Alempijević 2012: 51) kojim se označava sceničnost, izdvajanje određenih kulturnih elemenata i njihovo stavljanje u kontekst festivala. Festivalizirati kulturu znači "svaki dan učiniti praznikom” (isto: 52).

17 Pod strategijom festivalizacije, eventizacije i razvoja poduzetničkih kapaciteta u sklopu medijskog modela adventizacije zagrebačkih prostora misli se na skup kulturnih, urbanih, urbanoumjetničkih i poduzetničkih (ugostiteljskih) praksi kojima se u određenom razdoblju intervenira u prostor grada i utječe na život građana.

${ }^{18}$ www.adventzagreb.hr (pristup 10. 5. 2018.).

${ }^{19}$ Internetski portal European Best Destinations sa sjedištem u Bruxellesu osnovan je s ciljem promoviranja kulture i turizma u Europi. Od 2009. godine bira najbolje europske destinacije, a pobjedniku dodjeljuje titulu Best Christmas Market in Europe (www.europeanbestdestinations.com, pristup 20. 5. 2018.). 
sajma "Šećer dolazi na kraju... godine”, posjetitelje poziva na advent. U toj se marketinškoj pozivnici ističe reklama za Ledeni park - "najveće i najljepše klizalište u ovom dijelu Europe". ${ }^{20}$ Promotivni aspekt manifestacije najviše dolazi do izražaja u predimenzioniranom veličanju dionice Fuliranja ${ }^{21}$ koje "pretvara maštu u stvarnost, a snove u realnost". Poruka je jasna: "ova adventska atrakcija bit će sinonim za dobru zabavu, nezaboravne trenutke i najljepše adventske uspomene"22 što se dodiruje s nadnaslovom medijskog priloga o ovogodišnjem Fuliranju "Life is circus" (Golemac 2017). Ti se podaci višekratno ponavljaju u medijskim prilozima.

$\mathrm{Na}$ internetskim stranicama gradonačelnikove stranke također se ističe prilog "Najbolja adventska destinacija u Europi", te objašnjenje da je manifestaciju "pokrenuo gradonačelnik Milan Bandić 2010. godine". Njegova vizija Zagreba "kao grada prožetog božićnim ozračjem i duhom zajedništva" omogućuje domaćim i stranim gostima "bogatu kulturnu, gastro i rekreativnu blagdansku ponudu". ${ }^{23}$ Poruka je jasna: bez gradonačelnika ne bi bilo ni manifestacije niti adventskog duha u gradu. Turistička zajednica grada Zagreba na svojim službenim stranicama naglašava komercijalni i turistički efekt, te poručuje da će manifestacija "kao i lanjskih godina pridonijeti rastu turističkog prometa u Zagrebu". ${ }^{24}$

Istraživanje je pokazalo da je u većini analiziranih priloga u Jutarnjem listu i Večernjem listu izrazito prisutan diskurs koji su kreirali marketinški stručnjaci, odnosno nekritičko prenošenje informacija iz promidžbenih materijala koji su objavljeni na službenim internetskim stranicama inicijatora i organizatora manifestacije. Ti mediji u svoje priloge, nabijene oduševljenjem, zanosom i euforijom, prepisuju i upisuju viziju i ciljeve organizatora, a zatim njihovu poruku o adventu kao "najznačajnijoj zagrebačkoj turističkoj manifestaciji"25 distribuiraju čitateljima. Takva je praksa najuočljivija u prilozima Jutarnjeg lista, u kojima je utvrđeno odsustvo analitičkog i kritičkog diskursa te prosudbe manifestacije Advent u Zagrebu. Takvim informativnim modelom zapravo se dovodi u pitanje vjerodostojnost tih priloga.

Međutim, zbog načina glasovanja dovedena je u pitanje vjerodostojnost i natječaja i titule Zagreba kao Best Christmas Marketa. Naime, kritičari su tvrdili da je Zagreb osvojio tu titulu zato što su za njega glasovali samo Hrvati. No, to je na portalu index.hr u prosincu 2016. godine demantirao Maximilien Lejeunem, izvršni direktor portala, koji je rekao da bi Zagreb pobijedio i da nije bilo glasova iz Hrvatske jer je bez njih imao 23088 glasova što je i dalje više od prošlogodišnjeg drugorangiranog na listi gradova, Strasbourga, koji je imao 19242 glasa (https://www.index.hr/vijesti/clanak/advent-u-zagrebu-na-meti-kritika-je-li-natjecajnamjesten-evo-sto-smo-otkrili/938129.aspx, pristup 16. 9. 2018.).

Perrine Bertrand iz European Best Destinations u prosincu 2017. također je istaknula da bi Zagreb i bez glasova iz Hrvatske (38,2 posto) odnio pobjedu. Nacionalna potpora samo je dokaz da se događaj sviđa i samim građanima Hrvatske te da ga žele podijeliti s turistima (https://www.index.hr/magazin/clanak/ saznali-smo-bi-li-advent-u-zagrebu-bio-najbolji-u-europi-da-hrvati-nisu-glasali/1013259.aspx, pristup 16. 9. 2018.).

\footnotetext{
${ }^{20}$ www.adventzagreb.hr (pristup 10. 5. 2018.).

${ }^{21}$ Fuliranje je jedna od lokacija na manifestaciji Advent u Zagrebu (Strossmayerov trg).

22 www.adventzagreb.hr (pristup 10. 5. 2018.).

${ }^{23}$ http://www.365ris.hr/portfolio/advent-u-zagrebu-2/ (pristup 10. 5. 2018.).

24 http://www.tzgz.hr (pristup 10. 5. 2018.).

${ }^{25}$ http://www.tzgz.hr/aktualnosti/advent-u-zagrebu (pristup 10. 5.2018.).
} 
Stoga se može reći da je medijska prezentacija Adventa u Zagrebu svojevrsni odraz i pokazatelj copy-paste kulture, koja je prisutna i u hrvatskim medijima te društvu u cjelini. To potvrđuju, primjerice, euforične formulacije u prilozima Jutarnjeg lista, poput "najbolji europski advent”, 26 "najbolji božićni program u Europi” (Golemac 2018), "bajkovito mjesto" (Macukić 2017a) i "trijumf u jakoj konkurenciji",27 koje u sličnim varijantama pronalazimo i u službenim promidžbenim materijalima organizatora i promotora manifestacije Advent u Zagrebu.

U članku "Copy-paste kultura" Sead Alić se osvrće na "nekritičko i doslovno preuzimanje čitavih dijelova teksta" kao i na to da digitalno doba "prenosi iskustvo umnažanja u neistraženu dimenziju kloniranja mišljenja, rezultata znanstvenih istraživanja, načina analiziranja i sl., dovodeći nas u potpuno novu situaciju" (Alić 2008: 65-66). Na kraju zaključuje da "u copy-paste kulturi opstaje samo ono što se može digitalizirati, a digitalizira se ono što je podobno mediju, odnosno medijskim moćnicima" (isto: 72).

Takav marketinški diskurs i postupak kopipejstanja podataka sa službenih stranica organizatora pobuđuje sumnju u pretvaranje medija u alat kojim se posreduju informacije od organizatora i upravnih struktura grada Zagreba do čitatelja. U tom slučaju možemo se zapitati radi li se tu o indirektnom oglašavanju pod krinkom autorskog teksta koji bi trebao dobiti oznaku "plaćeni oglas", dakle o pokušaju manipulacije informacijama, ili se samo radi o niskom stupnju autonomije, ${ }^{28}$ kreativnosti, pa čak i lijenosti novinara. S druge strane, model izvještavanja u kojem je naglasak na revijalnom i zabavnom tonu, bez obzira na to je li riječ o "kloniranju" službenih dokumenata, agencijske produkcije, ili o vlastitoj proizvodnji vijesti, uklapa se u uređivački koncept tog nacionalnog dnevnika. Naime, Jutarnji list je od osnutka 1998. godine strukturiran kao polutabloid i može se reći da je s tim nacionalnim dnevnikom hrvatska medijska scena ušla u razdoblje tzv. entertainment novinarstva, koje se temelji na oblikovanju informacije na zabavan i ležeran način. ${ }^{29}$ Također, strategija kopipejstanja informacija ukazuje na kreativnu i autorsku krizu današnjeg novinarstva u Hrvatskoj, a poziva i na razmišljanje o tome koliko su hrvatski mediji politički i ekonomski neovisni te vjerodostojni.

S druge strane, sličnost sadržaja i tona priloga na službenim stranicama Adventa u Zagrebu i u analiziranim prilozima moguće je povezati s idejom Dunje Rihtman-Auguštin o uspostavljanju novog kalendara u Hrvatskoj, koju u slučaju adventa podupiru i mediji. Autorica je još 1992. godine ustvrdila kako "nova vlast u Hrvatskoj ima izraziti smisao za

26 https://www.jutarnji.hr/dobrahrana/price/ultimativna-adventska-ruta-slijedite-djedicu-na-12-kucicana-adventu-koje-ne-smijete-propustiti/6862431/ (pristup 12. 4. 2018.).

27 https://www.jutarnji.hr/life/advent-zagreb/video-posjetitelji-odabrali-najbolju-adventsku-lokaciju-zagreba-odusevili-tisuce-zbog-urbanog-koncepta-lijepih-standova-i-dobre-hrane/6883596/ (pristup 8. 4. 2018.).

${ }^{28}$ Autonomija ovisi, prema Bourdieu, između ostaloga, o "sposobnosti autonomne produkcije informacija" (Bourdieu 2000: 95).

${ }^{29}$ Takav tip novinarstva karakterizira prezentacija ozbiljnih tema, primjerice s područja politike ili kulture, na zabavan, estradiziran način u formi kraćih tekstova, s velikim, prepoznatljivim fotografijama i pretjerivanjima u naslovima. 
simbole, rituale i kićene proslave" te ih "uporno organizira, bez obzira na ratno vrijeme i gospodarske nedaće" (Rihtman-Auguštin 1992: 36). U nastavku je istaknula da je potvrdu hipotezi "da ta tendencija ide iz samoga vrha, lako naći" (isto), a tu tezu je argumentirala razgovorom s Franjom Tuđmanom, objavljenim u Nedjeljnom Vjesniku pod naslovom "Hrvatska pred duhovnom obnovom",30 u kojem je tadašnji predsjednik države, kako je istaknula, "posve nedvosmislen" (isto). "Rituale, po njegovu mišljenju, neophodno je potrebno uspostavljati jer su oni činilac organizacije države i reda što upućuje na to da se novi politički i državni sustav svjesno služi više ili manje novim ritualima i povijesnim simbolima" (isto: 36-37).

Autorica je nadalje pojasnila da je nova hrvatska vlast osjetila potrebu da zakonski učvrsti godišnji kalendar svojih blagdana te zaključila da se novi službeni kalendar u Hrvatskoj odlikuje "oživljavanjem narodnih praznika vezanih uz katoličku vjersku tradiciju poput Božića i Uskrsa te dana Svih Svetih" (isto: 39). U već spomenutoj knjizi Ulice moga grada autorica ističe da bismo u razdoblju od pedesetih do sredine osamdesetih "mogli govoriti o dekristijanizaciji kao političkoj tendenciji" (Rihtman-Auguštin 2000: 111), dok je "neposredni tijek političkih događaja potkraj osamdesetih najavio spajanje populističkih pokreta, nacionalizam i rekristijanizaciju" (isto). Slijedom autoričina razmišljanja, može se postaviti hipoteza da je i današnja gradska vlast odustala od "'potiranja rituala', o kojem govori P. Burke (1987.)" (isto) i manifestacijom Advent u Zagrebu pokušala rekristijanizirati narodnu kulturu.

Potrebno je spomenuti i viđenje Anke Mišetić, koja govori o porastu javnog svetkovanja u Hrvatskoj u posljednjim trima desetljećima 20. stoljeća, te spominje "transformaciju postojećih, vraćanje nekih starih i stvaranje novih gradskih rituala” (Mišetić 2004: 9). Petra Kelemen i Nevena Škrbić Alempijević (2012) u knjizi Grad kakav bi trebao biti obrazlažu da su festivali postali vlasništvom zajednice, koja se prepoznaje u određenoj manifestaciji i uspostavlja komunikaciju s građanima.

U svakom slučaju, sajmovi, svetkovine, festivali i slične manifestacije reflektiraju slojevitost društva i različite oblike dokolice, ukusa, kao i potrebu građana da se otrgnu rutini svakodnevice i svom životu daju dozu svečarskog tona. Festivalom se generiraju neke nesvakidašnje aktivnosti i neuobičajeni doživljaji (isto: 51), što je vidljivo i na primjeru adventa. No prožimanje festivalskog i svakodnevnog postaje još vidljivije ako organizatori festivala i kreatori kulturnih politika pojedine teme koje se promiču festivalom trajno upišu u gradsko tkivo (isto: 409). Je li manifestacijom Advent u Zagrebu uspostavljen most do "grada kakav bi trebao biti - grada kreativnosti, stvaranja, radoznalosti, smijeha i otkrivanja, koji pruža priliku za mnoštvo susreta i interakcija, pruža mogućnost novih iskustava" (isto: 17-18)?

${ }^{30}$ U spomenutom intervjuu (Nedjeljni Vjesnik, 1992) tadašnji predsjednik države Franjo Tuđman definira svoje viđenje duhovne obnove te ulogu inteligencije i crkve u "uspostavi prosudbenog sustava". 


\section{MODELI MEDIJSKE PREZENTACIJE SAJMA ADVENT U ZAGREBU}

Istraživanje ukazuje da u izvještavanju analiziranih medija o manifestaciji Advent u Zagrebu prevladavaju četiri modela medijske prezentacije: prvo, zagrebački Advent se predstavlja kao najbolja, najzanimljivija, najromantičnija "blagdanska čarolija u gradu" (Golemac 2018) s "velikim bubblastim iznenađenjima"; 31 drugo, kao "novi street gastrotainment"32 s naglaskom na "žuji, kobasici, germknedli i street sarmi”; treće, kao prilika za uspješan studentski ili obiteljski biznis te obilnu i kratkoročnu zaradu; i četvrto, kao eksploatator gradske i parkovne baštine.

\section{MODEL "BLAGDANSKE ČAROLIJE U GRADU"}

Vizualni identitet festivala predstavlja jednu od strategija kojima se formira festivalska autentičnost (Kelemen i Škrbić Alempijević 2012). Jedna od bitnih karakteristika medijskog ocrtavanja posebnosti manifestacije Advent u Zagrebu odnosi se na ambijentalnost i sceničnost prostora te bajkovitost ugođaja što tu manifestaciju izdvaja iz rutine svakodnevnice. U ovom modelu medijske prezentacije zagrebačkog adventa kao "blagdanske čarolije u gradu" (Golemac 2018) s "velikim bubblastim iznenađenjima”33 zagrebački božićni sajam predstavlja se nekritičkim panegiricima u kojima se superlativima uzdiže blagdanska, romantična atmosfera i redizajnirani prostor Zagreba. Vizualno i scenski transformirani prostor grada i novostvoreni identitet Zagreba kao čarobne, romantične, bajkovite turističke destinacije opisuje se kao "najčarobnije mjesto" i "najromantičnija lokacija ovogodišnjeg Adventa” (Staničić 2017), "najbolji božićni sajam u Europi” (Balija 2017b), "najbolji Advent u Europi” (Bertek 2017), "blagdanska bajka” (Balija i Ružić 2017), te "bajkovito mjesto" i "vrhunske blagdanske atrakcije" (Macukić 2017a). Tako detektirana i plasirana značenja argumentiraju se priznanjima koja je zagrebački advent dobio na rang listama svjetskih portala, kao što su, primjerice, European Best Destinations i CNN. ${ }^{34}$

Valja reći da je iz tih priloga vidljivo da mediji dramatiziraju, prenaglašavajući važnost i ljepotu vizualnog identiteta manifestacije, te time potvrđuju Bourdieuovu tezu da današnji mediji "koriste neobične, jake riječi, kojima se imenuje slika, odnosno, događaj, situacija, lik" (Bourdieu 2005: 270). Slično razmišlja i politolog Thomas Meyer, koji iznosi ideju o

31 http://www.jutarnji.hr/life/advent-zagreb/foto-pogledajte-poseban-program-koji-su-pripremili-za-ba dnjak-jako-dobra-glazba-jos-bolja-hrana-i-velika-bubblasta-iznenadenja/6866694 (pristup 9. 5. 2018.).

${ }^{32}$ https://www.jutarnji.hr/life/advent-zagreb/video-posjetitelji-odabrali-najbolju-adventsku-lokaciju-zagreba-odusevili-tisuce-zbog-urbanog-koncepta-lijepih-standova-i-dobre-hrane/6883596/ (pristup 8. 4. 2018.).

33 https://www.jutarnji.hr/life/advent-zagreb/foto-pogledajte-poseban-program-koji-su-pripremili-zabadnjak-jako-dobra-glazba-jos-bolja-hrana-i-velika-bubblasta-iznenadenja/6866694/ (pristup 9. 5. 2018.).

34 https://www.jutarnji.hr/life/advent-zagreb/foto-cnn-uvrstio-zagreb-na-popis-najboljih-svjetskih-bozicnih-sajmova-jos-jedno-veliko-priznanje-nasem-adventu-a-posebno-im-se-svidio-jedan-detalj/6821 (pristup 11. 4. 2018.). 
medijskom konstruiranju stvarnosti pomoću mehanizama dramatizacije, teatralizacije i zabavne inscenacije te prenaglašenog korištenja vizualnih elemenata čime se preuveličava značaj određenog događaja ili osobe, te time proizvodi promišljeni učinak na publiku i konstruira nova stvarnost (Meyer 2003: 61-71).

Medijski napisi usredotočeni su i na brojne transformacije zagrebačkih lokacija, od Gornjeg grada preko Trga bana Jelačića do Zrinjevca i Trga kralja Tomislava, u kojima se pokazuje kako se svakodnevni prostori pretvaraju u blještave festivalske scenografije (pozornice, drvene kućice, panoi s porukama, svjetleći dekor, klizalište). No djeluju li takvi medijski prikazi kao "reflektirajuća ljepota" ili "više kao narkotici" te vode stanju, kako je ustvrdio medijski teoretičar Marshal McLuhan, "obamrlosti i samoamputaciji" (McLuhan 2008: 41-46)? Mediji također dobro zapažaju zaposjedanje i osvajanje prostora grada tijekom trajanja adventa te donose karte festivalskog grada (Golemac 2017) koje posjetiteljima omogućuju bolje snalaženje u festivalskim programima.

Mediji detektiraju i tzv. šetanje, karakteristično za festivale i slične ulične manifestacije, kao i mehanizam selfie dokumentiranja zagrebačkog adventa:

Uzbuđeni su bili baš svi koji su se ovog vikenda našli na ulicama. Adventska groznica, sa simptomima dobrog raspoloženja i pretjeranog smijeha, zahvatila je i najveće "Grincheve", a nikome nisu smetale ni gužve koje su se stvarale na ulazima na blagdanske lokacije, ali i na gradskim ulicama. U kolonama se hodalo od Glavnog kolodvora do Trga bana Jelačića, pa i do Gornjeg grada. Selfiji su se snimali na svakom koraku, posebice u Marićevu prolazu, koji je ukrašen bijelim granama posutima LED lampicama [...]. (Balija i Ružić 2017)

Taj prilog sugerira težnju stanovnika Zagreba za raznim oblicima dokolice i razbibrige, da se otrgnu rutini svakodnevnice i barem za vrijeme adventa spektakulariziraju stvarnost i uobičajenom načinu života pridodaju svečarski ugođaj. A možda sugerira i proizvodnju "privida, proračunatu iluziju o stvarnosti [...], kojem u stvarnom životu ne odgovara ništa drugo do inscenacijska kalkulacija autora tog privida" (Meyer 2003: 61-62).

S druge strane, mediji u toj blještavoj ikonografiji i bajkovitoj atmosferi novog adventskog grada ne primjećuju proizvoljnu upotrebu prošlosti, odnosno korištenje simbola poput Charlesa Dickensa ${ }^{35}$ koji nemaju nikakve veze s poviješću i tradicijom grada Zagreba.

${ }^{35}$ http://www.vecernji.hr/vijesti/ulica-kao-iz-doba-charlesa-dickensa-1211740 (pristup 12. 4. 2018.). 


\section{MODEL PREZENTACIJE KAO "STREET GASTROTAINMENT" MANIFESTACIJE}

Prilozi u drugom modelu medijske prezentacije usmjereni su na zagrebački advent kao na značajnu "street gastrotainment"36 manifestaciju. U tom modelu Zagreb se promovira kao nova "street-food"37 destinacija gdje se ulični ugostitelji koriste strategijom predstavljanja originalnih i manje originalnih delikatesa poput Burgera od Romanovski janjetine do El Toro Chorizo hobotnice, ali i uobičajenije ponude u stilu “žuje, kobasice, germknedli i street sarmi".

Naglasak na kulinarskim temama može se objasniti njihovom iznimnom popularnošću, ali i tržišnom logikom. Takvi sadržaji narasli su do nivoa žanra te se danas može naći izuzetno veliki broj magazina, časopisa, knjiga, filmova, televizijskih emisija, televizijskih mreža i internetskih blogova koji govore o pripremi i dekoraciji hrane, odnosno o zdravoj ishrani i nutritivnim vrijednostima različitih hranjivih namirnica. "Gledatelji pokazuju istinski interes za hranu i aktivno sudjeluju u stvaranju takvih emisija postavljajući pitanja i tražeći savjete putem mejla, telefonskim pozivima ili sudjelovanjem u publici tijekom snimanja" (Matwick i Matwick 2015: 2). Iznimnu popularnost i važnost hrane zapaža i Jelena Ivanišević, koja piše o nastanku i razvoju žanra gastronomske književnosti u Hrvatskoj te napominje da se takva literatura analogno chick-litu naziva i kitch-litom (Ivanišević 2017). Robin Fox prepoznaje hranu kao snažan oblik socijalizacije te navodi da "konzumiranje obroka često postaje socijalni trenutak, pa čak i izlika za druženje" (Fox 2006: 1) što se pokazuje i na adventu.

U skladu s tom globalnom medijskom fascinacijom kulinarstvom i promoviranjem najrazličitijih nacionalnih kuhinja putem različitih TV formata, elektronički mediji koji su analizirani u ovom radu donose niz članaka, fotoreportaža i kulinarskih vodiča (Veliki vodič dobre hrane) u kojima se na zapanjujuće detaljan način analizira, recenzira i rangira gastro ponuda (Božić 2017b). Prilažu se i interaktivne karte najbolje uređenih i ukrašenih kućica na adventu ${ }^{38}$ i tlocrti lokacija s gastro ponudom kao i cjenicima delicija na Trgu bana Jelačića, Zrinjevcu, Arheološkom muzeju, Tomislavovom trgu, Klovićevim dvorima, Strossu (Macukić 2017b). Prilozi donose i recepte neobičnih specijaliteta, a medijski "kulinarski znalci" vrednuju gastro ponudu i raspravljaju o kvaliteti određenih specijaliteta, primjerice kobasica (Badanjak 2017), fritula (Balija 2017a) ili germknedli (Božić 2017a). Uspoređuju se i okusi i sastojci dva sendviča istovjetnog naziva - Philly cheesesteak - koji su kupljeni u

36 https://www.jutarnji.hr/life/advent-zagreb/video-posjetitelji-odabrali-najbolju-adventsku-lokaciju-zagreba-odusevili-tisuce-zbog-urbanog-koncepta-lijepih-standova-i-dobre-hrane/6883596/ (pristup 8. 4. 2017.).

37 https://www.jutarnji.hr/life/advent-zagreb/video-posjetitelji-odabrali-najbolju-adventsku-lokaciju-zagreba-odusevili-tisuce-zbog-urbanog-koncepta-lijepih-standova-i-dobre-hrane/6883596/ (pristup 8. 4. 2017.).

38 https://www.jutarnji.hr/dobrahrana/price/ultimativna-adventska-ruta-slijedite-djedicu-na-12-kucicana-adventu-koje-ne-smijete-propustiti/6862431/ (pristup 12. 4. 2018.). 
dvjema različitim kućicama (Babić i Šarić 2017b). Premda se kulinarska ponuda najčešće ocjenjuje u superlativima, kao što su "nikad bogatija gastro ponuda" (Bertek 2017), "prava poslastica” (Babić i Šarić 2017a), "originalna slatko-slana iznenađenja” (Golemac 2017), "kvaliteta mesa na zavidnoj razini” (Babić i Šarić 2017a), te "dojmljiva prezentacija jela" i "vrhunska gurmanska street ponuda", 39 u nekim se prilozima (Jutarnji list, Telegram) ukazuje i na propuste u kulinarskoj ponudi. Primjerice, bilježi se da je tijesto germknedle, inače jednoga od favorita zagrebačkog adventa, "bilo bezukusno i uvelike nalik kruhu, a umak nije bio dovoljno sladak i nedostajalo mu je aromatične vanilije. Punjenje od pekmeza je bilo prekiselo, a germknedlu smo platili 35 kuna” (Babić i Šarić 2017b).

U medijskim prilozima o kulinarskoj ponudi dominiraju atraktivne fotografije koje se pojavljuju kao logičan i prirodan način predstavljanja proizvoda. Ljubica Janjetović u članku “Hrana kao medijski spektakl (ili gdje je nestalo Džejmijevo brašno?)" kaže kako "fotografije djeluju razoružavajuće na kritičku recepciju fetišizirane robe i mentalne procese čitatelja" (Janjetović 2013: 134), te takav “medijagenični”40 (Aubenas i Benasayag 2005: 317-322) prikaz hrane izaziva zbog vizualne privlačnosti potrebu za konzumacijom. Meyer ističe aspekt "estetizacije socijalnog svijeta kao dominacije vizualnog u odnosu prema pisanoj riječi" te da zato slika "ne djeluje samo kao medij u socijalnom svijetu nego ona nanovo konstruira taj svijet" (Meyer 2003: 57-60). Jean Baudrillard smatra da društvu glavni pečat daje vladavina slika, a također spominje dijaboličko zavođenje slike te ističe da je slika zanimljiva tek kada počne kontaminirati i modelirati stvarno (Baudrillard 2001). Dakle, medijageničnost je vrlo bitna kod poticanja publike, bilo na kupovinu, bilo na upijanje sadržaja.

Savršene slike hrane imaju jedinstvenu moć koja privlači publiku i utječe na njih na drugačiji način nego što to čine tekstualni mediji te su "glatki i sjajni" prehrambeni proizvodi u medijima orijentirani na zabavu i imaju tendenciju da "onesposobe" pojedince koji ne razumiju kako se proizvodi ovakav sadržaj, što može potaknuti [jedino] pasivni angažman. (Janjetović 2013: 136)

Mediji naglašavaju kako se ulični ugostitelji trude da svake sezone unesu nešto novo u adventsku gastro ponudu. lako je "street sarma" bila "jedan od hitova [...] carstva zagrebačkog Adventa” 2017. godine (Trstenjak 2017), otkriva se i da su u ponudu uključene i “španjolske fritule i germknedle punjene nutelom, koje se rade u Austriji", a jedna od poduzetnica ističe i kako su u ponudu “dodali i churrose koje je naučila raditi u Španjolskoj" (Boltižar i Bertek 2017).

39 https://www.jutarnji.hr/life/advent-zagreb/video-posjetitelji-odabrali-najbolju-adventsku-lokaciju-zagreba-odusevili-tisuce-zbog-urbanog-koncepta-lijepih-standova-i-dobre-hrane/6883596/ (pristup 8. 4. 2018.).

40 Pojam medijageničnost dolazi od termina fotogeničnost i njime se definira sposobnost ljudi da uspješno medijatiziraju svoj nastup, od izgleda do prezentacije teme, ili na medijski atraktivan način prikažu neki objekt. 
Konačno, jedan od priloga, a riječ je o članku "Svaka kućica na zagrebačkom Adventu dnevno baci 2,5 kg hrane" ${ }^{41}$ objavljenom u Večernjem listu, pozornost javnosti preusmjerava na problem bacanja hrane, koji je evidentan u kontekstu te manifestacije. $U$ tom prilogu predstavljena je inicijativa zagrebačkih studenata aktivista koji u spotu "Time 4 a Change" upozoravaju na bacanje neprodane hrane na adventu i zatim predlažu zakonsko legaliziranje održivog sustava otpisa hrane što bi pak omogućilo darivanje hrane potrebitima i gladnima. Objavljivanjem tog priloga Večernji list pokazuje osjetljivost prema socijalno ugroženim skupinama građana.

\section{MODEL PREZENTACIJE ADVENTA KAO PRILIKA ZA USPJEŠAN BIZNIS}

Od triju modela medijske prezentacije zagrebačkog adventa najmanje je zastupljen onaj u kojem prevladava poslovni i financijski diskurs što je logično jer se ne radi o specijaliziranim poslovnim dnevnicima i portalima. U medijskim prilozima objavljenima u Večernjem listu i Jutarnjem listu advent se prikazuje kao prilika za uspješan studentski ili obiteljski biznis, odnosno kao novi poslovni model malih poduzetnika, najviše uličnih ugostitelja, koji u toj manifestaciji vide izvrsnu mogućnost za sezonsko zapošljavanje i zaradu, ali i za iskazivanje osobnih i još neiskazanih poslovnih afiniteta i talenata.

U tom je modelu pozornost medija usredotočena na sudionike adventa - obrtnike i proizvođače hrane (ugostitelji, kuhari, prodavači) koji su predstavljeni kroz tzv. success story ili personality story (Meyer 2003 : 25), koje su sve prisutnije u entertainment novinarstvu, o čijim je značajkama već bila riječ. Castells ističe kako se u medijskoj prezentaciji javlja proces "personalizacije događaja kao moćno sredstvo vobličavanja političkih vijesti u kojemu glavni akter drame više nije politika već ličnost političara" (Castells 2002: 328). Proces personalizacije događa se u medijskoj prezentaciji gotovo svih sfera društva, od kulture do sporta i zabave, te se reflektori usmjeravaju na osobe - u slučaju adventa na ugostitelje. Iz medijskih je napisa vidljivo da su ugostitelji očekivano za vrijeme adventa izrazito angažirani i zaposleni te motivirano osmišljavaju svoje kulinarske proizvode. Zajedničko im je vjerovanje "da mogu ostvariti profit i da će se ovo pokazati kao dobra poslovna odluka” (Boltižar 2017a).

Medijski prilozi najčešće donose, kako je već napomenuto, success story. Jedna od njih je priča o dvojici studenata, Dinu i Petru, koji su upravo na adventu odlučili započeti samostalni ugostiteljski biznis (Boltižar 2017a). Prilog "Dao sam otkaz, posudio lovu od mame i brata, čak sam uzeo i novac od kuma za krizmu" govori "o mladiću čiji je štand postao daleko najveći hit Adventa" jer na njemu prodaje "tradicionalno hrvatsko jelo u ne baš tradicionalnom izdanju - sarmu u pecivu, kojom je unio malu revoluciju u gastronomsku adventsku ponudu" (Boltižar 2017b) Na adventu je uspio spojiti svijet ekonomije i hrane "što

${ }^{41}$ https://www.vecernji.hr/zagreb/svaka-kucica-na-zagrebackom-adventu-dnevno-baci-2-5-kg-hrane1217309 (pristup 12. 4. 2018.). 
mu je zapravo otkrilo posao kojim se želio baviti u životu" (Boltižar 2017b). Pozornost se, također, posvećuje i zaradi koju donosi takav posao. Primjer je tomu članak "Dobar posao na adventu: iako se na najboljim lokacijama najam plaća i do 90 tisuća kuna, pogledajte koliko novca vlasnici kućica zarade za 40 dana!" koji donosi simulaciju poslovanja jedne adventske kućice gdje je metodom okvirnog izračuna navedeno da se tijekom 39 dana “ovogodišnje sezone adventskih kućica može zaraditi 104.550 kuna” (Vranković 2017).

U ovom modelu medijske prezentacije uočljivo je povezivanje adventa s konzumerizmom i potrošačkim, trgovačkim duhom. Naglašava se, dakle, komercijalni efekt sajma, sajam kao poslovna prilika za zaradu ugostitelja, odnosno onih sudionika sajma koji zapravo, koristeći izuzetno kreativnu božićnu industriju, advent pretvaraju u festival potrošnje i zarade.

\section{MODEL PREZENTACIJE ADVENTA KAO EKSPLOATATORA BAŠTINE}

Nužno je spomenuti i četvrti, istraživačko-novinarski model medijske prezentacije adventa, koji uključuje priloge objavljene $u$ elektroničkom tjedniku Telegram i elektroničkom izdanju Novosti, a koji izuzetno promišljeno i argumentirano donose analizu manifestacije Advent u Zagrebu. Takav model prezentacije adventa u spomenutim izdanjima zapravo je očekivan s obzirom na njihove uređivačke koncepcije koje obilježava (posebno Novosti) analitički i izrazito kritički diskurs. Riječ je o svega trima prilozima, preciznije tematskim člancima u kojima autori povezuju socijalni trenutak Hrvatske s rastrošnošću na adventu (Novosti), odnosno apeliraju na neprimjerenost eksploatacije kulturne, prirodne i arhitektonske baštine (Telegram).

Sveučilišni profesor Mate Kapović ustvrdio je za Novosti "da advent nije namijenjen većini stanovnika Hrvatske, njih 2,7 milijuna, koji na računu imaju manje od deset tisuća kuna i žive od plaće do plaće, te da je adventska ponuda cijenom namijenjena uglavnom višoj srednjoj klasi i imućnijim građanima" (Grozdanić 2017). Istaknuo je, također, kako se adventu ne može veseliti ni više od 60 tisuća blokiranih Zagrepčana, kao ni 553 bivša radnika Diokija kojima za neisplaćene plaće duguju ukupno 90 milijuna kuna. Naglasio je i povezanost gradonačelnika Zagreba s degradacijom javnog prostora:

Za sve što gradonačelnik Milan Bandić radi - bile to fontane ili socijalni stanovi - tipični su dealovi s podobnim kapitalom kao i potpuna degradacija javnog prostora, gdje glavni zagrebački trg većinu godine više sliči na vašar nego na trg. Sam Advent je pak dobra maska za ono što se krije ispod toga: bezbrojne zatvorene radnje u širem centru grada koje su posljedica slabo profitabilnog perifernog kapitalizma i gradske fasade u raspadanju. (Grozdanić 2017)

U elektroničkom tjedniku Telegram povjesničarka zagrebačkog urbanizma Snješka Knežević analizira pogreške (u izgledu, stilu i sadržaju) zagrebačkog adventa te ukazuje na ključne 
razlike u proizvodnji i prezentaciji adventskog sadržaja u Zagrebu i ostalim gradovima, ponajviše u Beču (Knežević 2018). ${ }^{42}$

Snješka Knežević u svojoj se analizi, potkrijepljenoj brojnim fotografijama, osvrće na parkove kao nositelje kulturnog identiteta i urbaniteta Zagreba, a potom detektira sve elemente "vandalskog uništavanja" (Knežević 2018) povijesnih parkova u Gornjem i Donjem gradu (Park Bele IV., Trg kralja Tomislava, Zrinjevac, Strossmayerov trg...), postavljajući sljedeću tezu: stvaranje novog brenda Zagreba kroz adventsku čaroliju rezultira "totalnim ignoriranjem parka kao forme i formacije, spomenika i baštine na tim lokacijama", koje su nakon završetka priredbe "opustošene teškom mehanizacijom, strojevima, kamionima, kućicama i nogama posjetitelja”.

Posebno analizira Ledeni park na Trgu kralja Tomislava, "ikoni i simbolu epohe u kojoj je Zagreb postao moderni grad", koji smatra najvećim krimenom adventa. Konstatira da "u potrazi za efektima i inovacijom dokoni akupunkteri i poduzetna projektantica evenata uoče i zgrabe taj tradicijom posvećen prostor kao mjesto gdje će stvoriti svoj i novi brand - mjesto koje odavno ima karakter organskog brenda, postojanijeg od svakog umjetno stvorenoga". Autorica definira Ledeni park kao "dozlaboga banalno mobilno klizalište, kakvih ima u bezbroj europskih, američkih, azijskih i drugih gradova”, a zatim poziciju klizališta usred središnjeg zagrebačkog parka uspoređuje s pozicijama klizališta te značenjem parkova u europskim gradovima. Ustvrđuje da, primjerice, na kultiviranim površinama bečkih parkova Burggarten i Volksgarten nema ni klizališta niti komercijalnih koliba/ kioska, nego su ti parkovi "najreprezentativniji dio urbane baštine - autentični brendovi, esencija identiteta i štićena baština". Stoga se u prilogu pita zašto nikome od projektnih menedžera i arhitekata zagrebačkog adventa nije palo na um da predloži klizalište na srednjoškolskom igralištu gdje ledena površina ne bi dezavuirala zelenu.

Knežević u prilogu konstatira i kako "od navodno golemog novca uprihođenog Adventom, ni lipe ni centa nije utrošeno na obnovu ili popravak kulise njegovih evenata: kuća i palača, ulica i trgova, a osobito parkova". Argumentiranom faktografijom razotkriva plasiranje lažnih "činjenica” u medijima od strane stručnjaka (arhitekata i ravnatelja određenih muzeja), što dovodi do toga da se na temelju tih netočnih ili namjerno krivotvorenih podataka stvara pogrešna slika o povijesti Zagreba. Primjerice, nasuprot podacima koje su u medijskim izjavama iznijeli pojedini stručnjaci, Knežević ističe da staro zagrebačko klizalište nije bilo postavljeno 1877. na glavnom zagrebačkom trgu jer je tamo bilo "glavno gradsko dnevno tržište", a niti u atriju Klovićevih dvora, gdje je u to vrijeme bilo Glavno vojno zapovjedništvo za Hrvatsku i Slavoniju. Obznanjuje da je klizalište ispred Rathausa u Beču, nazvano Ledeni san, veće od zagrebačkog za čak osam tisuća četvornih metara! Tim podatkom izravno se suprotstavlja tvrdnji iznesenoj na službenoj stranici sajma Ad-

${ }^{42}$ Uredništvo donosi podatak da je taj članak pročitalo čak deset tisuća ljudi, a dobio je i 3132 preporuke, što ne iznenađuje s obzirom na profesionalni ugled autorice članka te popularnost teme kao što je zagrebački advent. 
vent u Zagrebu ${ }^{43}$ prema kojoj je zagrebačko klizalište na Trgu kralja Tomislava "najveće u ovom dijelu Europe". Je li ovdje riječ o izvorno politički proizvedenoj laži koju hrvatski mediji nekritički perpetuiraju?

Horkheimer i Adorno svoju tvrdnju o manipulativno-propagandnom utjecaju medija obrazložili su analizom korištenja masovnih komunikacija u doba uspona nacizma u Njemačkoj, kada su mediji postali instrument političke i ideološke propagande (Horkheimer i Adorno 1989: 126-172). Chomsky pak navodi termin "povijesno upravljanje" (Chomsky 2006: 41) kojim upućuje na proces dizajniranja povijesnih činjenica na način da služe politici. Ističe i mehanizme "kontrole mišljenja" kojima država nastoji umjetno ili nasilu kontrolirati ljudske misli, odnosno način razmišljanja.

Knežević postavlja i pitanje legitimnosti nominiranja, glasovanja i navijanja na internetskom portalu European Best Destinations. S obzirom na tržište od pola milijarde ljudi, napominje da "[n]asumičnim pregledom drugih portala, kao što su mirror.co.uk, telegraph. co.uk, nypost.com, skyscanner.net, travelaway.me... među ocijenjenim božićnim sajmovima nema ZG-adventa" odnosno, nastavlja autorica, "na jednom od njih: edition.cnn. com/travel od 15 kandidata Zagreb je na četrnaestom, pretposljednjem mjestu, što se čini realnim, poznaje li se i površno što se i gdje nudi u Europi” (Knežević 2018). Radi li se i tu o medijskom zavođenju i manipuliranju?

Knežević na kraju zaključuje:

ZG-advent: njegov izgled i stil, sadržaj i poslovanje odraz je karaktera i morala, naobrazbe i kulture njezinih glavnih protagonista: gradonačelnika Milana Bandića i Martine Bienenfeld, direktorice Turističke zajednice Zagreba. Oni raspolažu gradom. Tako će biti dok budu na svojim pozicijama. O njima ovisi hoće li Zagreb poći putem eventizacije i festivalizacije, razvojnim strategijama tipičnim za globaliziranu neoliberalnu ekonomiju - ili će ga neki drugi usmjeriti drukčijim putovima. (Knežević 2018)

\section{ZAKLJUČAK}

Analizirana internetska izdanja Jutarnjeg lista i Večernjeg lista učestalo, opširno i pohvalno izvješćuju o manifestaciji Advent u Zagrebu, koju prepoznaju i prezentiraju kao uspješan, vizualno atraktivan gastro-turistički proizvod. Taj proizvod definiraju kao sintezu blještave blagdanske čarolije, kulinarstva i biznisa u kojoj, s jedne strane, pozornost usmjeravaju na transformacije gradskih prostora, ležernu, opuštenu i bajkovitu atmosferu, uživanje u dokoličarenju i strategiju tzv. šetanja, tipičnog za festivale, a s druge na domaće, ali i uvozne specijalitete uličnih ugostitelja. Za razliku od tih dnevnika, prilozi iz elektroničkih tjednika Telegram i Novosti analitičkim i kritičkim pristupom upozoravaju na negativne učinke adventske čarolije.

\footnotetext{
${ }^{43}$ www.adventzagreb.hr (pristup 10. 5. 2018.).
} 
Takva medijska prezentacija manifestacije Advent u Zagrebu zapravo je očekivana s obzirom na karakteristike izdavačkih i uređivačkih politika te profil i vlasničku strukturu medija čiji su prilozi analizirani u ovome radu. Naime, dnevnici Jutarnji list i Večernji list su nacionalni, komercijalni mediji, orijentirani prema tržištu, nalaze se u privatnom vlasništvu - Jutarnji list u vlasništvu hrvatske izdavačke korporacije Hanza media d.o.o., a Večernji list u vlasništvu austrijske korporacije Styria Press International sa sjedištem u Grazu. Obje novine, posebno Jutarnji list, strukturirane su kao polutabloidi što znači da imaju izražene značajke tzv. entertainment novinarstva. S obzirom na njihov dnevni ritam izlaženja, komercijalnu orijentaciju, tretiranje informacije kao robe i borbe za opstanak na medijskom tržištu, ti dnevnici u svojim uređivačkim politikama često posežu za "žutilom” i "senzacionalizmom". Dunja Majstorović kaže da želja za što bržim objavljivanjem informacija rezultira brzopletošću i greškama. "Te greške predstavljaju plodno tlo za različite propuste i neprimjereno izvještavanje, a u svrhu ispunjavanja osnovnog cilja novina - privlačenja pozornosti čitatelja i stjecanja što većeg profita - zanemaruju se osnovna načela dobrog novinarstva i odgovornost prema primateljima informacija" (Majstorović 2010: 55-64).

S druge strane, Telegram i Novosti u skladu sa svojim tjednim ritmom izlaženja na širi i analitičniji način pristupaju obradi sadržaja. Telegram je također privatni medij (Telegram media grupa d.o.o.), međutim, uređivačka koncepcija tog medija jasno je profilirana podnaslovom Portal za društvena i kulturna pitanja. I svijet koji dolazi čime je zapravo naglašena njegova orijentacija prema propitivanju i istraživanju suvremenih tema. Također, taj se tjednik na komercijalnom hrvatskom medijskom tržištu već profilirao kao medij koji istražuje, otkriva i kritički se odnosi prema stvarnosti. Tjednik Novosti jedini nema komercijalnu, tržišnu orijentaciju jer je financiran iz hrvatskog državnog proračuna. Izdaje ga Srpsko narodno vijeće no list je svojom uređivačkom i izdavačkom politikom prerastao interese srpske manjine i profilirao se kao politički tjednik izrazito kritičke i analitičke orijentacije.

Usporedbom službenih dokumenata Grada Zagreba i Turističke zajednice grada Zagreba i analiziranih medijskih priloga vidljiv je izraziti marketinški diskurs i mehanizam copy-paste medijske kulture. Ta kopipejstana informacija otkriva da gradska vlast, kao i Turistička zajednica, grade novi identitet Zagreba kao zabavnog, adventskog središta, a ne primjerice kao grada tolerancije i multikulturalnosti, čija bi se prepoznatljivost temeljila na kulturnom kapitalu iz prošlosti i sadašnjosti Zagreba te na gospodarskom uspjehu. Tome je pridonijela nezainteresiranost gradske kulturne politike za sustavnije osmišljavanje kulturnog programa na toj manifestaciji.

Advent u Zagrebu prepoznat je i kao važan politički resurs. Naime, u analiziranim medijima predstavljen je kao uspješan primjer rada gradskog vodstva, odnosno uspješne suradnje gradskih vlasti i Turističke zajednice grada Zagreba te biznisa malih poduzetnika. Zbog toga Advent u Zagrebu nije samo simbol božićnog ugođaja, potrošnje i zabave nego i politički simbol te simbol predbožićne marketinške industrije koja komercijalizira taj blagdan.

Mediji u prezentaciji Adventa u Zagrebu prvenstveno koriste model adventizacije zagrebačkih prostora, gdje se u skladu s tržišnom ekonomijom, potrošačkim duhom i aktualnim 
trendom desakralizacije adventa, a pomoću festivalizacije i eventizacije te poduzetničkim kapacitetima nastoji uspostaviti identitet Zagreba kao zabavne i poželjne turističko-gastronomske adventske metropole.

Drugim riječima, Zagreb svoju međunarodnu prepoznatljivost temelji na užitku, vrućim kobasicama i šarenom spektaklu, šaljući u svijet poruku o sebi kao adventskoj metropoli s "vrhunskom gurmanskom street ponudom i bubblastim iznenađenjima", što ga pretvara u poželjnu destinaciju zabave i slavljeničke atmosfere.

\section{NAVEDENA LITERATURA I IZVORI}

Alić, Sead. 2008. "Copy-paste kultura. Od 'Mehaničke mlade' do copy-paste kulture". Filozofska istraživanja 109: 65-66.

Aubenas, Florence i Miguel Benasayag. 2005. "Mali savjeti za one koji se žele pojaviti u medijima”. Europski glasnik 10: 317-322.

Babić, Vesna i Anita Šarić. 2017a. "Veliki vodič dobre hrane za Advent. Evo što probati, a što zaobići na poznatom zagrebačkom Fuliranju”. Jutarnji list, 7. 12. Dostupno na: https://www.jutarnji.hr/dobrahrana/price/veliki-vodic-dobre-hrane-evo-sto-probati-a-sto-zaobici-na-poznatom-zagrebackom-fuliranju/6821748/ (pristup 12. 4. 2018.).

Babić, Vesna i Anita Šarić. 2017b. "Veliki vodič dobre hrane za Advent. Konačno smo našli ukusne fritule i pili stvarno dobar grog, otkrili smo i vrijedi li taj čuveni sendvič 72 kune". Jutarnji list, 10. 12. Dostupno na: https://www.jutarnji.hr/dobrahrana/price/veliki-vodic-dobre-hrane-za-advent-konacno-smo-nasli-ukusne-fritule-i-pili-stvarno-dobar-grog-otkrili-smo-i-vrijedi-li-taj-cuveni-sendvic72-kune/6826011/ (pristup 8. 4. 2018.).

Badanjak, Iva. 2017. "Dva poznata kuhara odabrala najkobasicu adventa. Isprobali su 12 jela na različitim štandovima: 'Izvana je hrskavo, unutra mekano. Sve je kako treba'." Jutarnji list, 14. 12. Dostupno na: https://www.jutarnji.hr/dobrahrana/price/dva-poznata-kuhara-odabrala-najkobasicu-adventa-isprobali-su-12-jela-na-razlicitim-standovima-izvana-je-hrskavo-unutra-mekano-sve-je-kako-treba/6843891/ (pristup 12. 5. 2018.).

Balija, Petra. 2017a. "Testirali smo gastroponudu na adventu u Zagrebu. Evo kamo na kobase, fritule, vino...". Večernji list, 7. 12. Dostupno na: https://www.vecernji.hr/vijesti/advent-zagreb-hrana-fritule-kobasice-vino-1212485 (pristup 12. 5. 2017.).

Balija, Petra. 2017b. "Zagrebački advent opet najbolji u Europi". Večernji list, 12. 12. Dostupno na: https:// www.vecernji.hr/zagreb/advent-u-zagrebu-titula-najbolji-1213537 (pristup 15. 4. 2018.).

Balija, Petra i Jelena Ružić 2017. "Advent je ludilo, zbog ovoga se isplati i satima putovati”. Večernji list, 4. 12. https://www.vecernji.hr/vijesti/zagreb-advent-bozic-blagdani-1211766 (pristup 8. 4. 2018.).

Baudrillard, Jean. 2001. Simulacija i zbilja. Zagreb: Jesenski i Turk, Hrvatsko sociološko društvo.

Baudrillard, Jean. 2005. "Iznad istinitog i neistinitog". Europski glasnik 10: 189.

Berelson, Bernard. 1959. "The State of Communication Research". Public Opinion Quaterly 23: 1-6. https://doi.org/10.1086/266840

Bertek, Daria. 2017. “Foto: U Zagrebu je počeo najbolji Advent u Europi”. Jutarnji list, 2. 12. Dostupno na: https://www.jutarnji.hr/vijesti/zagreb/foto-u-zagrebu-je-poceo-najbolji-advent-u-europi-nikad-bogatija-gastro-ponuda-na-12-lokacija-u-samom-centru-grada-pogledajte-atmosferu-na-tomislavcu/6805314/ (pristup 12. 4. 2018.).

Boltižar, Matija. 2017a. "Ovo je priča o šestorici studenata koji su pokrenuli svoj biznis na adventu”. Jutarnji list, 6. 12. Dostupno na: https://www.jutarnji.hr/life/advent-zagreb/ovo-je-prica-o-sestorici-stu- 
denata-koji-su-pokrenuli-svoj-biznis-na-adventu-dino-je-na-petoj-godini-strojarstva-prije-10-dana-je-odlucio-otvoriti/6816315/ (pristup 12. 4. 2018.).

Boltižar, Matija. 2017b. "Dao sam otkaz, posudio lovu od mame i brata, čak sam uzeo novac od kuma za krizmu”. Jutarnji list, 6.12. Dostupno na: https://www.jutarnji.hr/life/advent-zagreb/dao-sam-otkazposudio-lovu-od-mame-i-brata-cak-sam-uzeo-i-novac-od-kuma-za-krizmu-prica-o-mladicu-cijije-stand-postao-daleko-najveci-hit-adventa/6816402/ (pristup 12. 4. 2018.)

Boltižar, Matija i Daria Bertek. 2017. "U hrvatsku metropolu stiže 200 tisuća gostiju! Očekuje se potrošnja od 500 milijuna kuna". Jutarnji list, 2. 12. Dostupno na: https://www.jutarnji.hr/life/adventzagreb/u-hrvatsku-metropolu-stize-200-tisuca-gostiju-ocekuje-se-potrosnja-od-500-milijuna-kuna-moze-li-i-do-trece-titule-zaredom/6800733/ (pristup 8. 4. 2018.).

Bourdieu, Pierre. 2000. Narcisovo ogledalo. Beograd: Clio.

Bourdieu, Pierre. 2005. "O televiziji. Pozornica i kulise”. Europski glasnik 10: 270-280.

Božić, Andrea. 2017a. "Germknedle su u Zagrebu još veći hit nego lani; probali smo ih sve, da vam olakšamo". Telegram, 7. 12. Dostupno na: https://www.telegram.hr/price/germknedle-su-u-zagrebu-josveci-hit-nego-lani-probali-smo-ih-sve-da-vam-olaksamo/ (pristup 12. 4. 2018.).

Božić, Andrea. 2017b. "Fritule su nekako postale glavna stvar na Adventu; isprobali smo 10 najambicioznijih da vam olakšamo izbor". Telegram, 26. 12. Dostupno na: https://www.telegram.hr/zivot/fritule-su-nekako-postale-glavna-stvar-na-adventu-isprobali-smo-10-najambicioznijih-da-vam-olaksamo-izbor/ (pristup 12. 4. 2018.).

Castells, Manuel. 2000. Uspon umreženog društva. Zagreb: Golden marketing - Tehnička knjiga.

Castells, Manuel. 2002. Moć identiteta. Zagreb: Golden marketing - Tehnička knjiga.

Chomsky, Noam. 2006. Mediji, propaganda, sistem. Dostupno na: http://www.elektronickeknjige.com/ chomsky_noam/mediji_propaganda_i_sistem/index.htm (pristup 15. 7. 2018.).

Chomsky, Noam. 2005. “Što čini dominantne medije dominantnima?”. Europski glasnik 10: 199-207.

Debord, Guy. 1999. Društvo spektakla. Zagreb: Arkzin.

Dumančić, Marija. 2016. “Adventizacija. Split ili Zagreb uz kuhano vino i kobasice”. Splitski dnevnik, 23. 12. Dostupno na: http://splitskidnevnik.rtl.hr/vijesti/hrvatska/adventizacija-split-ili-zagreb-uz-kuhano-vino-i-kobasice/ (pristup 18. 5. 2018.).

Fox, Robin. 2006. “Food and Eating. An Anthropological Perpective”. Dostupno na: http://www.sirc.org/ publik/foxfood.pdf (pristup 15. 5. 2018.).

Golemac, Sandra. 2018. "U 30 dana posjetitelji potrošili gotovo pola milijuna kuna”. Jutarnji list, 8. 1. Dostupno na: https://www.jutarnji.hr/life/advent-zagreb/u-30-dana-posjetitelji-potrosili-gotovo-pola-milijarde-kuna-zavrsio-najbolji-bozicni-program-u-europi-metropola-biljezi-rekordne-brojke-posjecenosti/6910800/ (pristup 8. 4. 2018.).

Golemac, Sandra. 2017. "Life is circus. Fuliranje na novoj lokaciji". Jutarnji list, 6. 12. Dostupno na: https:// www.jutarnji.hr/life/advent-zagreb/life-is-circus-fuliranje-na-novoj-lokaciji/6817053/ (pristup 17. 9. 2018.).

Grozdanić, Dragan. 2017. "Kod Milana u Sikret Gardenu”. Novosti, 28. 12. Dostupno na: https://www. portalnovosti.com/kod-milana-u-sikret-gardenu (pristup 12. 4. 2018.).

Horkheimer, Max i Theodor Adorno.1989. Dijalektika prosvjetiteljstva: Filozofijski fragmenti. Sarajevo: Veselin Masleša, Svjetlost.

Hromadžić, Hajrudin. 2011. “Mediji i spektakularizacija društvenog svijeta. Masmedijska produkcija 'kulture slavnih"'. Filozofska istraživanja 30/4: 617-627.

Ivanišević, Jelena. 2017. Od kuharice do književnosti. Ogledi o kulinarskoj prozi. Zagreb: Institut za etnologiju i folkloristiku.

Janjetović, Ljubica. 2013. “Hrana kao medijski spektakl (ili Gdje je nestalo Džejmijevo brašno?)”. Komunikacija i kultura online 4: 134-136. 
Kelemen, Petra i Nevena Škrbić Alempijević. 2012. Grad kakav bi trebao biti. Etnološki i kulturnoantropološki osvrti na festivale. Zagreb: Naklada Jesenski i Turk.

Knežević, Snješka. 2018. “Najvažnija povjesničarka zagrebačkog urbanizma. Što je sve pogrešno s izgledom, stilom i sadržajem Adventa". Telegram, 11. 01. Dostupno na: https://www.telegram.hr/price/ najvaznija-povjesnicarka-zagrebackog-urbanizma-sto-je-sve-krivo-s-izgledom-stilom-i-sadrzajem-adventa/ (pristup 15. 4. 2018.).

Labus, Mladen, ur. 2000. "Religijske promjene i vrijednosti u hrvatskom društvu". Sociologija sela (supplement) 1/2: 1-311.

Lasswell, Harold D. 1948. "The Structure and Function of Communication in Society". U The Communication of Ideas. Lyman Bryson, ur. New York: Harper and Brothers, 37-40.

Macukić, Viktorija. 2017a. "Advent ispod zemlje. Božićna scenografija i adventske pjesme”. Jutarnji list, 6. 12. Dostupno na: https://www.jutarnji.hr/life/advent-zagreb/advent-ispod-zemlje-bozicna-scenografija-i-adventske-pjesme/6818433/ (pristup 8. 4. 2018.).

Macukić, Viktorija. 2017b. “Advent u Zagrebu. Evo koje sve novosti donosi ove godine, nema više fuliranja kod uspinjače, seli se na drugu lokaciju!". Jutarnji list, 13. 11. Dostupno na: https://www.jutarnji.hr/ life/advent-zagreb/advent-u-zagrebu-evo-koje-sve-novosti-donosi-ove-godine-nema-vise-fuliranja-kod-uspinjace-seli-se-na-drugu-lokaciju/6742272/ (pristup 9. 4. 2018.).

Majstorović, Dunja. 2010. "Etički prijepori i vjerodostojnost dnevnih novina”. Medijske studije 1: 55-64.

Matwick, Kelsi i Keri Matwick. 2015. "Inquiry in Television Cooking Shows". Dostupno na: https://www.researchgate.net/publication/277629992_Inquiry_in_television_cooking_shows (pristup 15. 8. 2018.).

McLuhan, Marshall. 2008. Razumijevanje medija. Mediji kao čovjekovi produžeci. Zagreb: Golden marketing - Tehnička knjiga.

Mišetić, Anka. 2004. Gradski rituali. Retradicionalizacija društvenog života u gradovima nakon 1990. Zagreb: Hrvatska sveučilišna naklada.

Meyer, Thomas. 2003. Mediokracija. Medijska kolonizacija politike. Zagreb: Fakultet političkih znanosti.

Rihtman-Auguštin, Dunja. 1992. "O konstrukciji tradicije u naše dane. Rituali, simboli i konotacije vremena". Narodna umjetnost 29: 25-43.

Rihtman-Auguštin, Dunja. 2000. Ulice moga grada. Beograd: XX vek.

Staničić, Vjeko. 2017. "Zimski ugođaj u Zagrebu. Romantičan advent na Gornjem gradu”. Jutarnji list, 6. 12. Dostupno na: https://www.jutarnji.hr/life/advent-zagreb/zimski-ugodaj-u-zagrebu-romantican-advent-na-gornjem-gradu/6818583/ (pristup 20. 4. 2018.).

Trstenjak, Jasmina. 2017. "Dobar posao na Adventu. Prodali smo čak 500 porcija hrane u šest dana, a bilo bi ih i duplo toliko da smo ih imali više". Jutarnji list, 10. 12. Dostupno na: https://www.jutarnji. $\mathrm{hr} /$ biznis/karijere/dobar-posao-na-adventu-prodali-smo-cak-500-porcija-sarme-u-sest-dana-abilo-bi-ih-i-duplo-toliko-da-smo-ih-imali-vise/6830160/ (pristup 10. 4. 2018.).

Vranković, Lucija. 2017. "Dobar posao na Adventu. lako se na najboljim lokacijama najam plaća i do 90 tisuća kuna, pogledajte koliko novca vlasnici kućica zarade za 40 dana dana!". Jutarnji list, 6. 12. https://www.jutarnji.hr/life/advent-zagreb/dobar-posao-na-adventu-iako-se-na-najboljim-lokacijama-najam-placa-i-90-tisuca-kuna-pogledajte-koliko-novca-vlasnici-kucica-zarade-za-40-dana-rada/6816378/ (pristup 9. 4. 2018.). 


\section{MEDIA REPRESENTATION OF ZAGREB ADVENT:}

\section{BUSINESS, EXPLOITATION, IDENTITY}

This article provides a content analysis of the media coverage of the Advent in Zagreb in Croatian print and electronic media, more specifically the daily newspapers Jutarnji list and Večernji list and the weekly Internet portals Novosti and Telegram. The research focuses on whether the media presentation contributes only to the adventization and festivalization of Zagreb and the development of entrepreneurial capacities, or whether it also contributes to the creation of a new urban and cultural identity of Zagreb as a "Advent metropolis". The paper also seeks to examine the relationship between the media coverage and the city administration and what sort of identity the city of Zagreb authorities create through the Advent in Zagreb event. The paper also analyzes the uncritical and euphoric features of the new "advent" identity of Zagreb.

Keywords: Advent, media representation, Zagreb identity, "festivalization", "eventization" 